Research article

Open Access

\title{
Cytotoxic Compounds from Brucea mollis
}

\author{
Mai Hung Thanh Tung ${ }^{1}$, Ho Viet Đuc ${ }^{1}$, Tran Thu Huong ${ }^{1}$, \\ Nguyen Thanh Duong ${ }^{1}$, Do Thi PHUONG ${ }^{2}$, Do Thi THAO ${ }^{2}$, Bui HuU TAl ${ }^{3}$, \\ Young Ho KIM ${ }^{3}$, Tran The BACH ${ }^{4}$, Nguyen Manh CUONG ${ }^{*}$
}

${ }^{1}$ Institute of Natural Products Chemistry, VAST, 18 Hoang Quoc Viet street, Cau Giay, Hanoi, Vietnam.

2 Institute of Bioscience and Biotechnology, VAST, 18 Hoang Quoc Viet street, Cau Giay, Hanoi, Vietnam.

${ }^{3}$ College of Pharmacy, Chungnam National University, Daejeon 305-764, South Korea.

${ }^{4}$ Institute of Ecology and Biological Resources, 18 Hoang Quoc Viet street, Cau Giay, Hanoi, Vietnam.

*Corresponding author. E-mail: nmcuong_inpc@yahoo.com.vn (N. M. Cuong)

Sci Pharm. 2013; 81: 819-831

doi:10.3797/scipharm.1206-02

Published: $\quad$ December $31^{\text {st }} 2012$

Received: June $3^{\text {rd }} 2012$

Accepted: $\quad$ December $31^{\text {st }} 2012$

This article is available from: http://dx.doi.org/10.3797/scipharm.1206-02

(c) Tung et al.; licensee Österreichische Apotheker-Verlagsgesellschaft m. b. H., Vienna, Austria.

This is an Open Access article distributed under the terms of the Creative Commons Attribution License (http://creativecommons.org/licenses/by/3.0/), which permits unrestricted use, distribution, and reproduction in any medium, provided the original work is properly cited.

\begin{abstract}
Ten compounds, including soulameanone (1), isobruceine B (2), 9-methoxycanthin-6-one (3), bruceolline $F(4)$, niloticine (5), octatriacontan-1-ol (6), bombiprenone (7), $\alpha$-tocopherol (8), inosine (9), and apigenin 7-O- $\beta$-Dglucopyranoside (10), were isolated from the leaves, stems, and roots of Brucea mollis Wall. ex Kurz. Their structures were determined using one- and twodimensional NMR spectroscopy and mass spectrometry. All compounds were evaluated for their cytotoxic activity against KB (human carcinoma of the mouth), LU-1 (human lung adenocarcinoma), LNCaP (human prostate adenocarcinoma), and HL-60 (human promyelocytic leukemia) cancer cell lines. Compound 2 showed significant cytotoxic activity against KB, LU-1, LNCaP, and HL-60 cancer cells with $\mathrm{IC}_{50}$ values of $0.39,0.40,0.34$, and $0.23 \mu \mathrm{g} / \mathrm{mL}$, respectively. In addition, compounds 3 and 5 showed significant cytotoxic activity against $\mathrm{KB}, \mathrm{LU}-1, \mathrm{LNCaP}$, and $\mathrm{HL}-60$ cancer cells with $\mathrm{IC}_{50}$ values around 1-4 $\mu \mathrm{g} / \mathrm{mL}$. Compounds 9-methoxycanthin-6-one (3) and niloticine (5) have been discovered for the first time from the Brucea genus.
\end{abstract}

\section{Keywords}

Brucea mollis • Cytotoxicity • Quassinoids • Alkaloids • Triterpenoids 


\section{Introduction}

Brucea is a genus belonging to the family Simaroubaceae. It contains about six species mainly distributed in the tropical Eastern Hemisphere and found in Vietnam, China, northern Australia, and other Asian countries [1].

There are six Brucea species that have been chemically and biologically characterized: Brucea javanica, Brucea mollis var. tonkinensis, Brucea mollis, Brucea sumatrana, Brucea antidysenterica, and Brucea amarissima. Many compounds have been isolated from this genus, including quassinoids, alkaloids, triterpenoids, and flavonoids. Among these, quassinoids, a chemical class isolated only from the Simaroubaceous species, are the dominant constituents [2]. According to Ho, 2000, the Brucea genus in Vietnam consists of three species: $B$. javanica, B. mollis, and B. tonkinensis [3]. Up until now, there were some reports on the chemistry and bioactivity of Brucea mollis in Japan [4] and China [5]. However, the plant Brucea mollis collected in Vietnam has not been studied so far.

The results of the present study demonstrated that the methanol extract and n-hexane fraction from $B$. mollis leaves showed strong cytotoxic activity against three cancer cell lines: LU-1 (human lung adenocarcinoma), Hep G2 (liver hepatocellular carcinoma), and MCF-7 (human breast adenocarcinoma) [6].

In this paper, we report the bioactivity-guided isolation of ten compounds, i.e., soulameanone (1), isobruceine B (2), 9-methoxycanthin-6-one (3), bruceolline $F(4)$, niloticine (5), 1-octatriacontan-1-ol (6), bombiprenone (7), $\alpha$-tocopherol (8), inosine (9), and apigenin 7-O- $\beta$-D-glucopyranoside (10), from the leaves, stems, and roots of $B$. mollis. In addition, we examined the cytotoxic activity of these compounds against KB (carcinoma of the mouth), LU-1 (lung adenocarcinoma), LNCaP (human prostate adenocarcinoma), and HL-60 (promyelocytic leukemia) human cancer cell lines.

\section{Results and Discussion}

Compound 1 was obtained as a white powder. Its molecular formula was determined to be $\mathrm{C}_{20} \mathrm{H}_{28} \mathrm{O}_{8}$ on the basis of HR-ESI-MS $\left(\mathrm{C}_{20} \mathrm{H}_{29} \mathrm{O}_{8}, \mathrm{~m} / \mathrm{z} 397.3403[\mathrm{M}+\mathrm{H}]^{+}\right)$. The ${ }^{1} \mathrm{H} \mathrm{NMR}$ spectrum of 1 showed resonances ascribable to one olefinic methyl $(\delta 1.93, \mathrm{H}-18)$, one methyl $(\delta 0.92, \mathrm{H}-21)$, two tertiary methyls $(\delta 1.05, \mathrm{H}-19 ; 1.36, \mathrm{H}-20)$, one olefinic proton $(\delta$ $5.97, \mathrm{H}-3)$, one methylene $(\delta 2.08, \mathrm{H}-6)$, and five methines bearing oxygen at $\delta 3.5-5.0$.

The ${ }^{13} \mathrm{C}$ and DEPT NMR spectra of 1 revealed 20 carbon signals, including four methyls, one methylene, seven methines, and eight non-hydrogenated carbons. The ${ }^{13} \mathrm{C}-\mathrm{NMR}$, HSQC, and HMBC spectra showed that 1 was a quassinoid with a picrasane skeleton. As compared with data reported by Polonsky et al., 1980, 1 was determined to be soulameanone, a quassinoid isolated from Soulamea muelleri [7].

Compound 2 was obtained as a yellow powder. The ${ }^{13} \mathrm{C}-\mathrm{NMR}$ spectra of 2 were similar to those of soulameanone, with additional signals due to the methyleneoxy bridge between the C-8 and C-13 carbons and two substituted groups at the C-13 and C-15 carbons.

The ${ }^{13} \mathrm{C}$ and DEPT-NMR (90 and 135) spectra of 2 showed 22 carbon signals, including four methyls, two methylenes, nine methines, and seven non-hydrogenated carbons. The 
${ }^{1} \mathrm{H}-,{ }^{13} \mathrm{C}-\mathrm{NMR}, \mathrm{DEPT}, \mathrm{HSQC}$, and HMBC spectra of 2 showed one $\alpha, \beta$-unsaturated ketone group at $\delta 196.9$ (C-2), 124.3 (C-3), 162.9 (C-4), one ketone group ( $\delta$ 166.8, C-16), one carbomethoxy group $(\delta 172.6,53.0)$, and one acetyl group ( $\delta 169.0 ; 20.3)$.

Compound 2 was a C-20 pentacyclic quassinoid with two side chains at the C-13 and C-15 carbons, as indicated in the HMBC spectra. The mass spectrometric (ESI-MS) data for 2 showed a molecular ion peak at $\mathrm{m} / \mathrm{z} 480.7[\mathrm{M}+\mathrm{H}]^{+}$. Based on these data and a comparison with data reported by Fukamiya, 1988 [8], cpd. 2 was determined to be isobruceine B.

Compound 3 was obtained as a yellow powder from the $\mathrm{CH}_{2} \mathrm{Cl}_{2}$ fraction of the stems and roots of $B$. mollis. The molecular formula of 3 was determined to be $\mathrm{C}_{15} \mathrm{H}_{10} \mathrm{~N}_{2} \mathrm{O}_{2}$ on the basis of HR-ESI-MS $\left(\mathrm{C}_{15} \mathrm{H}_{11} \mathrm{~N}_{2} \mathrm{O}_{2}, \mathrm{~m} / \mathrm{z} 251.0820[\mathrm{M}+\mathrm{H}]^{+}\right)$. The ${ }^{1} \mathrm{H}$ NMR spectrum of 3 showed one ortho-coupled signal at $\delta 6.93(\mathrm{~d}, \mathrm{~J}=9.5 \mathrm{~Hz}, \mathrm{H}-5), 7.98(\mathrm{~d}, \mathrm{~J}=9.5 \mathrm{~Hz}, \mathrm{H}-4)$, two vicinal protons at $7.80(\mathrm{~d}, \mathrm{~J}=5.0 \mathrm{~Hz}, \mathrm{H}-1), 8.74(\mathrm{~d}, \mathrm{~J}=5.0 \mathrm{~Hz}, \mathrm{H}-2)$, three aromatic protons of a 1,3,4-substituted benzene ring at $\delta 8.16(\mathrm{~d}, \mathrm{~J}=2.0 \mathrm{~Hz}, \mathrm{H}-8), 7.04(\mathrm{dd}, \mathrm{J}=8.5$, $2.0 \mathrm{~Hz}, \mathrm{H}-10), 7.90(\mathrm{~d}, \mathrm{~J}=8.5 \mathrm{~Hz}, \mathrm{H}-11)$, and one methoxyl signal at $\delta 3.98(\mathrm{~s}, \mathrm{H}-17)$, corresponding to the carbon at $\delta 56.0$ (C-17). In addition, the $\mathrm{HMBC}$ correlation of $\mathrm{H}_{3}-17$ methoxyl protons to aromatic carbon C-9 suggested that the position of the methoxyl group was C-9. Based on the HMBC, COSY spectra of 3, and comparisons with previously reported data [9], compound $\mathbf{3}$ was determined to be 9-methoxycanthin-6-one.

The ${ }^{1} \mathrm{H},{ }^{13} \mathrm{C}$ NMR of 4 showed an indole glycoside structure indicated by the presence of a 3-substituted indole moiety. It was characterized by five aromatic protons at $\delta 7.54(\mathrm{~d}, \mathrm{~J}=$ $7.5 \mathrm{~Hz}, \mathrm{H}-4), 7.50$ (d, J = 8.0 Hz, H-7), 7.12 (t, J = 7.5 Hz, H-6), 7.03 (t, J = 7.5 Hz, H-5), and a singlet proton at $\delta 7.28(\mathrm{~s}, \mathrm{H}-2)$. The presence of a $\beta-\mathrm{O}-\mathrm{D}$-glucopyranoside group in 4 was characterized by six carbon signals at $\delta$ 84,5 (C-1"), 79,3 (C-5"), 77,5 (C-3"), 71,9 (C-2"), 70,0 (C-4"), 61,0 (C-6"), and an anomeric proton at $\delta 5.37$ (d, $\left.\mathrm{J}=9.5 \mathrm{~Hz}, \mathrm{H}-1^{\prime \prime}\right)$. Based on ${ }^{13} \mathrm{C},{ }^{1} \mathrm{H}$ NMR, HMBC, COSY, and NOESY analysis and comparisons with data reported in the literature [10], compound 4 was determined to be bruceolline $F$.

Compound 5 was obtained as a yellow powder from the $\mathrm{CH}_{2} \mathrm{Cl}_{2}$ fraction of the stem and roots of Brucea mollis. The molecular formula of $\mathbf{5}$ was determined to be $\mathrm{C}_{30} \mathrm{H}_{48} \mathrm{O}_{3}$ on the basis of HR-ESI-MS $\left(\mathrm{C}_{30} \mathrm{H}_{49} \mathrm{O}_{3} \mathrm{~m} / \mathrm{z}: 457.3682[\mathrm{M}+\mathrm{H}]^{+}\right)$. The ${ }^{13} \mathrm{C}$ and DEPT NMR spectra of 5 revealed 30 carbon signals, including eight methyls, eight methylenes, seven methines, six non-hydrogenated carbons, and one carbonyl group. Compound $\mathbf{5}$ had three carbons bearing oxygen at $\delta 69.3(\mathrm{t}, \mathrm{C}-23), 68.5(\mathrm{~d}, \mathrm{C}-24), 60.3$ (s, C-25), and only two olefinic carbons at $\delta 118.0(\mathrm{~d}, \mathrm{C}-7)$ and 145.7 (s, C-8). Artane triterpene 5 showed spectral patterns indicating the presence of an alkyl 24,25-epoxy side chain at C-17 carbon. Compound 5 was identified as niloticine by comparing its 1D, 2D-NMR spectral data with those in the literature [11].

Some other compounds were also isolated from the leaves, stem, and roots of $B$. mollis, including 1-octatriacontan-1-ol (6), bombiprenone (7), $\alpha$-tocopherol (8), one nucleoside, inosine (9), and one flavonoid, apigenin 7-O- $\beta$-D-glucopyranoside (10). Structures of all of the isolated compounds were determined on the basis of ${ }^{1} \mathrm{H},{ }^{13} \mathrm{C} \mathrm{NMR}$, and ESI-MS spectra, and were compared with references [12-14]. 


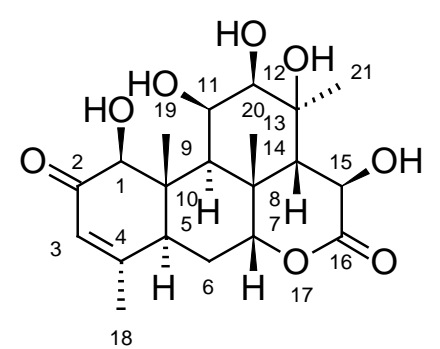

1

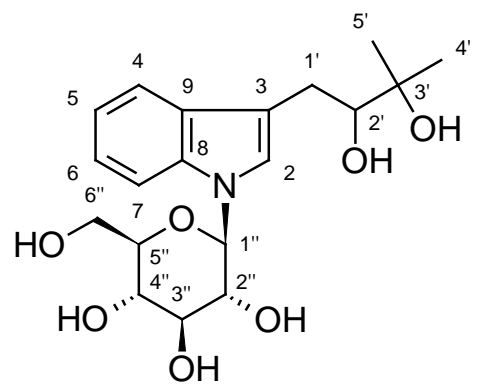

4

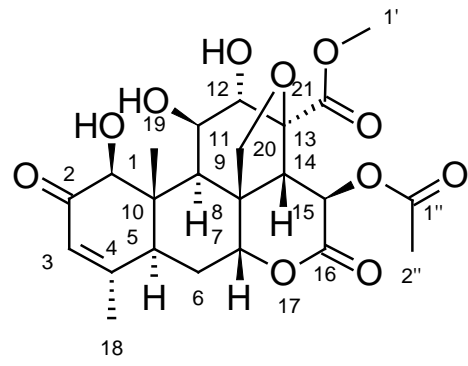

2

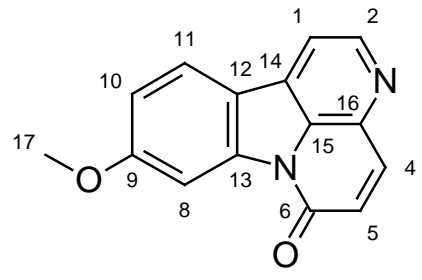

3

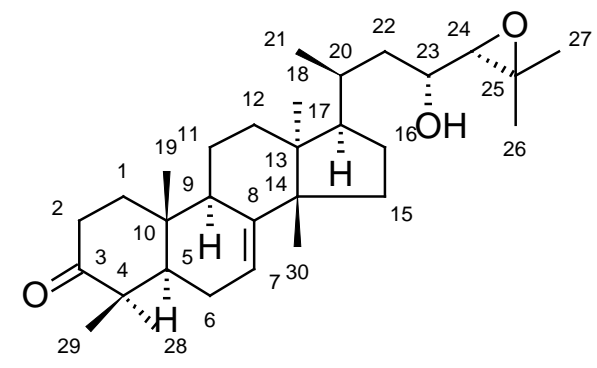

5<smiles>CCCCCCCCCCCCCCCCCCCCCCCCCCO</smiles>

6<smiles>CC(=O)CCC=C(C)CCC=C(C)CCC=C(C)CCC=C(Br)CCC=C(C)CCC=C(C)CCC=C(C)CCC=C(C)C</smiles>

7

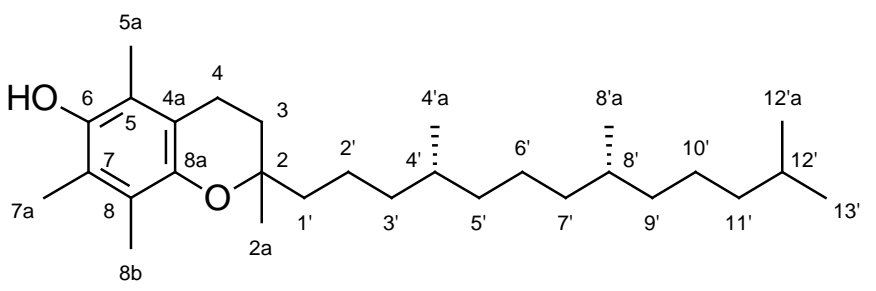

8<smiles>OC[C@H]1O[C@@H](n2cnc3c(O)ncnc32)[C@H](O)[C@@H]1O</smiles><smiles>O=c1cc(-c2ccc(O)cc2)oc2cc(OC3OC(CO)[C@H](O)[C@H](O)C3O)cc(O)c12</smiles>

10

Fig. 1. Compounds 1-10 
Tab. 1. Cytotoxicity of compound 1-10 against various cancer cell lines

\begin{tabular}{lcccc}
\hline Compound & \multicolumn{4}{c}{$\mathrm{IC}_{50}(\boldsymbol{\mu g} / \mathbf{m l})$} \\
\cline { 2 - 5 } & KB & LU-1 & LNCaP & HL-60 \\
\hline $\mathbf{1}$ & $>20$ & $>20$ & $>20$ & $>20$ \\
$\mathbf{2}$ & $\mathbf{0 . 3 9} \pm \mathbf{0 . 0 2}$ & $\mathbf{0 . 4 0} \pm \mathbf{0 . 0 1}$ & $\mathbf{0 . 3 4} \pm \mathbf{0 . 0 1}$ & $\mathbf{0 . 2 3} \pm \mathbf{0 . 0 3}$ \\
$\mathbf{3}$ & $\mathbf{3 . 7 3} \pm \mathbf{0 . 0 7}$ & $\mathbf{1 . 6 1} \pm \mathbf{0 . 0 6}$ & $\mathbf{1 . 0 1} \pm \mathbf{0 . 0 1}$ & $\mathbf{0 . 9 1} \pm \mathbf{0 . 0 1}$ \\
$\mathbf{4}$ & $>20$ & $>20$ & $>20$ & $>20$ \\
$\mathbf{5}$ & $\mathbf{2 . 2 2} \pm \mathbf{0 . 0 3}$ & $\mathbf{1 . 2 2} \pm \mathbf{0 . 0 3}$ & $\mathbf{1 . 1 0} \pm \mathbf{0 . 0 4}$ & $\mathbf{1 . 0 0} \pm \mathbf{0 . 0 2}$ \\
$\mathbf{6}$ & $>20$ & $>20$ & $>20$ & $>20$ \\
$\mathbf{7}$ & $>20$ & $>20$ & $>20$ & $>20$ \\
$\mathbf{8}$ & $>20$ & $>20$ & $>20$ & $>20$ \\
$\mathbf{9}$ & $>20$ & $>20$ & $>20$ & $>20$ \\
$\mathbf{1 0}$ & $>20$ & $>20$ & $>20$ & $>20$ \\
Ellipticine & $\mathbf{0 . 8 9} \pm \mathbf{0 . 0 2}$ & $\mathbf{0 . 7 2} \pm \mathbf{0 . 0 1}$ & $\mathbf{0 . 7 0} \pm \mathbf{0 . 0 2}$ & $\mathbf{0 . 6 6} \pm \mathbf{0 . 0 2}$ \\
\hline
\end{tabular}

The inhibitory activity of the isolated compounds was assessed using a cytotoxic assay against four cancer cell lines: KB (human carcinoma of the mouth), LU-1 (human lung adenocarcinoma), LNCaP (human prostate adenocarcinoma), and HL-60 (human promyelocytic leukemia). Those cell lines were selected based on the reason that KB cells were usually the classical cells used for all cytotoxic assays. Also, the others were employed in order to discover new activities of the tested compounds. The results showed that isobruceine B (2), 9-methoxycanthin-6-one (3), and niloticine (5) possessed strong inhibitory activities toward the tested cancer cell lines, with low $\mathrm{IC}_{50}$ values ranging from $0.23-0.4 \mu \mathrm{g} / \mathrm{mL}, 0.91-3.73 \mu \mathrm{g} / \mathrm{mL}$, and $1.00-2.22 \mu \mathrm{g} / \mathrm{mL}$, respectively (see Table 1 , Fig. 2). In particular, the cancerous cellular growth inhibitory activity of isobruceine B (2) was stronger than that of ellipticine, the positive control $\left(\mathrm{IC}_{50}\right.$ values ranging from $0.66-$ $0.89 \mu \mathrm{g} / \mathrm{mL}$ ). Isobruceine B was isolated from the wood of Brucea antidysenterica [15] with no biological activity reported, and from the stems of the Simaroubaceae Picrolemma sprucei plant, which was used in the Amazon regions of Peru, Brazil, and French Guiana as antimalarials [16]. Isobruceine B exhibited in vitro cytotoxic activities against SF-295, $\mathrm{HCT}-8$, and $\mathrm{HL}-60$ human tumor cells lines $\left(\mathrm{IC}_{50}=5-27 \mu \mathrm{g} / \mathrm{L}\right)$, and against the malarial multidrug-resistant Plasmodium falciparum K1 strain $\left(\mathrm{IC}_{50}=1.0-4.0 \mu \mathrm{g} / \mathrm{L}\right)$ [17].

Compound 2 had structural patterns of an anticancer quassinoid, including a four-ring skeleton with a lactone D-ring, an $\alpha, \beta$-unsaturated ketone in the A-ring, two free hydroxyl groups, an oxygen-methylene bridge in the C-ring, and an ester group at either the C-13 or C-15 position [18].

Some canthin-6-one alkaloids, commonly found in Eurycoma and Picrasma plants (Simaroubaceae family), showed in vitro inhibition of several cancer cell lines, including A-388, A549, MCF-7, and Bel-7402 [19, 20].

It is interesting to note that three cytotoxic compounds of different skeletons, i.e., quassinoid isobruceine $B$, alkaloid 9-methoxycanthin-6-one, and triterpene niloticine, were found in the Brucea mollis plant. Of those, 9-methoxycanthin-6-one (3) and niloticine (5) have been discovered for the first time from Brucea genus. 
A

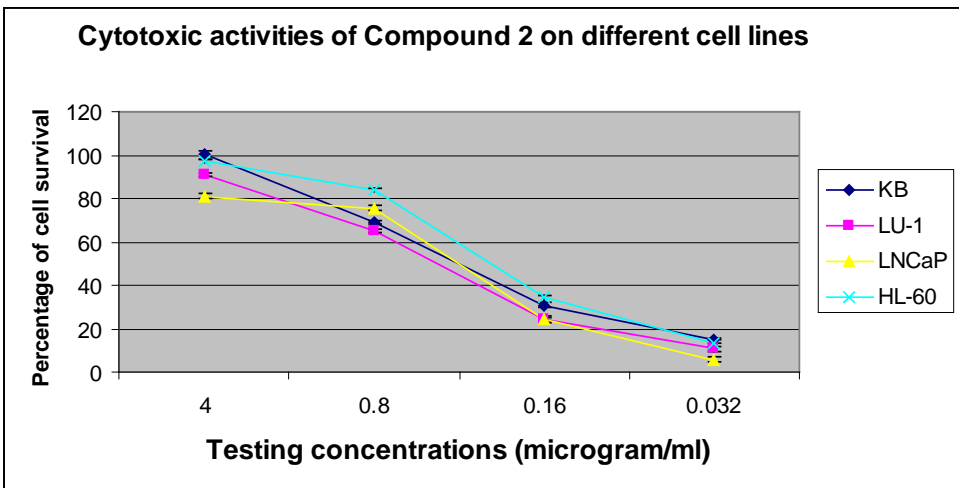

Cytotoxic activities of Compound 3 on different cell lines

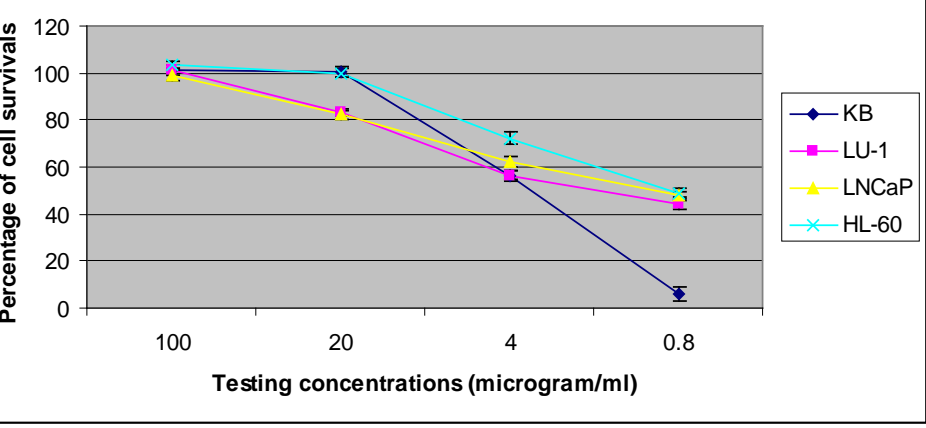

Cytotoxic activities of Compound 5 on different cell lines

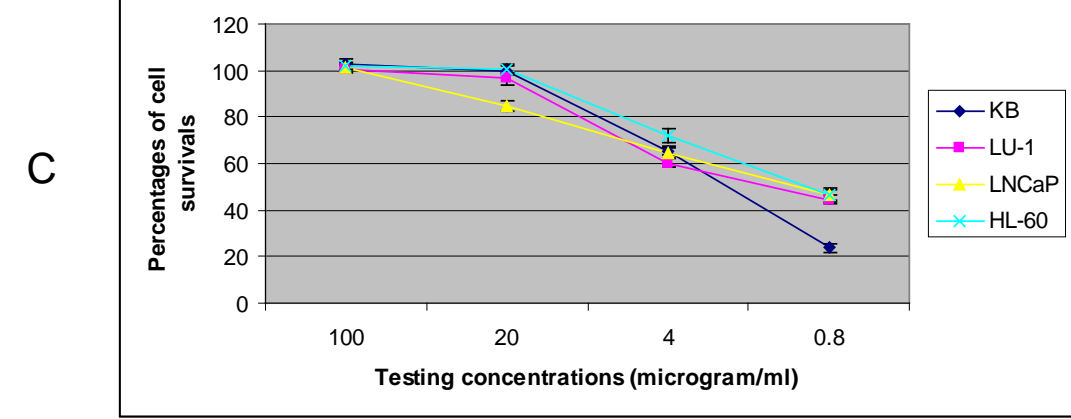

Cytotoxic activities of Ellipticine on different cell lines

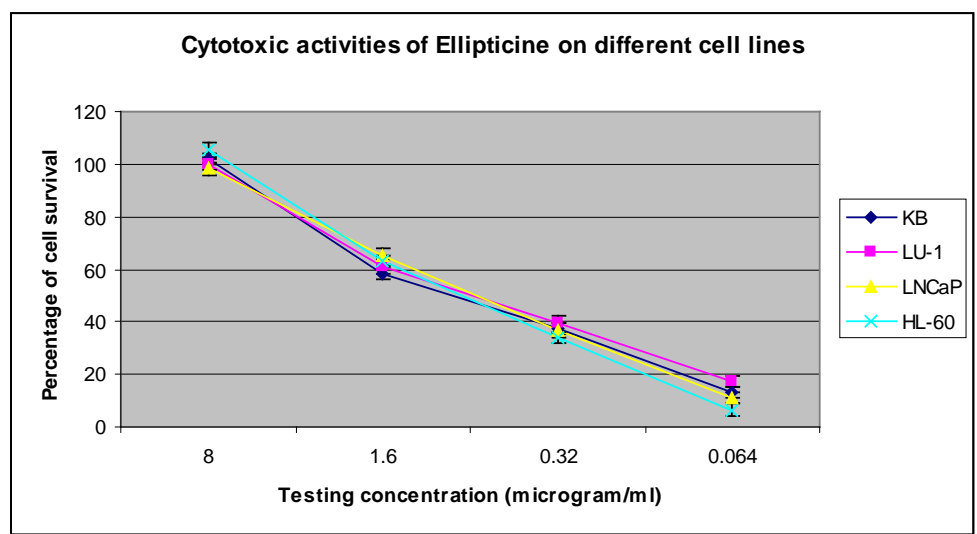

Fig. 2. A: cytotoxic activities of compound 2;

B: cytotoxic activities of compound 3;

C: cytotoxic activities of compound 5;

D: cytotoxic activities of ellipticine. 


\section{Experimental}

\section{General}

The 1D and 2D-NMR experiments were recorded on a Bruker Avance 500 (500 MHz for

${ }^{1} \mathrm{H}-\mathrm{NMR}$ and $125 \mathrm{MHz}$ for $\left.{ }^{13} \mathrm{C}-\mathrm{NMR}\right)$, using DMSO- $d_{6}$ and $\mathrm{CDCl}_{3}$ as solvents. ESI-MS was recorded on the Agilent 6310 Ion Trap, and HR-ESI-MS was recorded on the Agilent 6510 Q-TOF LC/MS. HPLC analysis was carried out on the Waters HPLC system, with the Waters 600 controller, Waters 600 pump, and Waters 996 photodiode array detector. Silica gel (70-230, 230-400 mesh, Merck), and YMC RP-18 resins (30-50 $\mu \mathrm{m}$, Fuji Silysia Chemical Ltd.) were used as absorbents in the column chromatography. Thin-layer chromatography (TLC) plates (Silica gel $60 \mathrm{~F}_{254}$ and RP-18 $\mathrm{F}_{254}, 0.25 \mu \mathrm{m}$, Merck) were purchased from Merck KGaA (Darmstadt, Germany). Spots were detected under UV radiation (254 and $365 \mathrm{~nm}$ ) and by spraying the plates with $10 \% \mathrm{H}_{2} \mathrm{SO}_{4}$ followed by heating with a heat gun.

\section{Plant material}

Brucea mollis (Wall. ex Kurz) was collected in March 2009 in the Hoa Binh province, Vietnam. The scientific name was identified by Dr. Tran The Bach, Institute of Ecology and Biological Resources, Vietnam Academy of Science and Technology. A voucher specimen (VK 2211(HN)) has been deposited in the herbarium of Institute of Ecology and Biological Resources.

\section{Extraction and isolation}

Dried powder from the leaves $(2.6 \mathrm{~kg})$, stems, and roots $(8.6 \mathrm{~kg})$ of $B$. mollis were extracted at room temperature with $\mathrm{MeOH}$ (three times $\times 72 \mathrm{~h}$ ). The solvent was removed under reduced pressure to obtain a residue $(191 \mathrm{~g})$ of leaves and a residue $(300 \mathrm{~g})$ of the stem and roots. These residues were suspended in water and partitioned with $n$-hexane, $\mathrm{CH}_{2} \mathrm{Cl}_{2}$, and EtOAc, successively.

A mixture of $\mathrm{n}$-hexane and $\mathrm{CH}_{2} \mathrm{Cl}_{2}$ fractions from the leaves (100 g) was subjected to column chromatography $(\Phi=15 \mathrm{~cm}$, height of silica gel $4 \mathrm{~cm}$ ) over silica gel and eluted with $\mathrm{CH}_{2} \mathrm{Cl}_{2}-\mathrm{MeOH}(100: 0,40: 1,20: 1,10: 1,5: 1,2.5: 1,1: 1,0: 100)$ to obtain eight fractions (1L each fraction). Fraction $3(27 \mathrm{~g})$ was separated by column chromatography over silica gel $\left(\Phi=10 \mathrm{~cm}\right.$, height of silica gel $20 \mathrm{~cm}$ ) and eluted with $\mathrm{CH}_{2} \mathrm{Cl}_{2}-\mathrm{MeOH}$ (gradient, $1-100 \%$, flow rate $5 \mathrm{ml} / \mathrm{min}$ ) to obtain 11 sub-fractions (Fr.1-Fr.11, $500 \mathrm{ml}$ each fraction). Sub-fraction $6(9 \mathrm{~g})$ produced a precipitate of crude crystals, which was separated by filtering and washing with acetone to yield compound $6(22 \mathrm{mg})$. Sub-fraction $2(5 \mathrm{~g})$ was separated by column chromatography $(\Phi=2.5 \mathrm{~cm}$, height of silica gel $70 \mathrm{~cm})$ and eluted with n-hexane-EtOAc (40:1, flow rate $2 \mathrm{ml} / \mathrm{min})$ to yield compound 7 (70 $\mathrm{mg})$ and compound 8 (75 mg).

After evaporation of the solvent, the EtOAc fraction from the leaves $(8 \mathrm{~g})$ was subjected to column chromatography over silica gel $(\Phi=3 \mathrm{~cm}$, height of silica gel $60 \mathrm{~cm})$ and eluted with acetone- $\mathrm{CHCl}_{3}-\mathrm{MeOH}(3: 1: 0.1)$ to obtain eight fractions (Fr.1-Fr.8). Fraction 2 (1 g) was separated over a YMC RP-18 column $(\Phi=2 \mathrm{~cm}$, height of silica gel $60 \mathrm{~cm})$ with $\mathrm{MeOH}$-water $(1: 4$, flow rate $0.5 \mathrm{ml} / \mathrm{min})$ to yield compound $1(60 \mathrm{mg})$. Fraction $4(1.5 \mathrm{~g})$ produced a precipitate of crude yellow crystals, which was separated by filtering and washing with $\mathrm{MeOH}$ to yield compound 10 (280 mg). 
The $\mathrm{CH}_{2} \mathrm{Cl}_{2}$ fraction of the stems and roots $(85 \mathrm{~g})$ was subjected to column chromatography over silica gel $(\Phi=15 \mathrm{~cm}$, height of silica gel $4 \mathrm{~cm})$ and eluted with $\mathrm{CH}_{2} \mathrm{Cl}_{2}-\mathrm{MeOH}(100: 0,40: 1,20: 1,10: 1,5: 1,2.5: 1,1: 1,0: 100)$, to obtain eight fractions (Fr.4A-4H, 1L each fraction). Fractions 4A and 4B were combined (31.5 g) and separated over silica gel $(\Phi=10 \mathrm{~cm}$, height of silica gel $20 \mathrm{~cm})$ with $n$-hexane-acetone $(3: 1,2: 1,1: 1$, flow rate $5 \mathrm{ml} / \mathrm{min}$ ) to obtain nine fractions (Fr.5A-5I, $500 \mathrm{ml}$ each fraction). Fraction $5 \mathrm{I}$ (2 g) was separated over silica gel $(\Phi=2 \mathrm{~cm}$, height of silica gel $60 \mathrm{~cm})$ with $\mathrm{CH}_{2} \mathrm{Cl}_{2}$-EtOAc (6:1, 5:1, 4:1, 1:1, flow rate $2.5 \mathrm{ml} / \mathrm{min})$ to yield compound 2 (70 $\mathrm{mg})$.

Fraction 5C (3.6 g) was separated over silica gel $(\Phi=2 \mathrm{~cm}$, height of silica gel $60 \mathrm{~cm})$ with $n$-hexane-EtOAc 6:1 to obtain seven fractions (Fr.6A-6G). Fraction 6E (120 mg) was separated over silica gel $(\Phi=1.5 \mathrm{~cm}$, height of silica gel $60 \mathrm{~cm}$ ) with n-hexane-EtOAc (6:1, flow rate $1.5 \mathrm{ml} / \mathrm{min})$ to yield compound 3 (50 $\mathrm{mg})$. Fraction $6 \mathrm{G}(250 \mathrm{mg})$ was separated with a YMC RP-18 column $(\Phi=2 \mathrm{~cm} \times 60 \mathrm{~cm})$ and eluted with MeOH-water $(1: 1.5,2: 1,4: 1$, flow rate $0.5 \mathrm{ml} / \mathrm{min})$ to yield compound 5 (100 $\mathrm{mg})$.

The water fractions of the stems and roots $(150 \mathrm{~g})$ were subjected to the Dianion HP-20 column $(\Phi=10 \mathrm{~cm}$, height of materials $30 \mathrm{~cm}$ ) and eluted with stepwise increases of $\mathrm{MeOH}$ in water $(25,50,75$, and $100 \%, 1 \mathrm{~L}$ each fraction). The fraction eluted by $25 \%$ $\mathrm{MeOH}(9 \mathrm{~g})$ was separated over silica gel $(\Phi=3 \mathrm{~cm}$, height of silica gel $60 \mathrm{~cm})$ with $\mathrm{CH}_{2} \mathrm{Cl}_{2}-\mathrm{MeOH}$-water (4:1:0.1, flow rate $2.5 \mathrm{ml} / \mathrm{min}$ ) to obtain 12 fractions. Fraction 11 (500 $\mathrm{mg})$ was separated by column chromatography over silica gel $(\Phi=2 \mathrm{~cm}$, height of silica gel $60 \mathrm{~cm})$ and eluted with acetone-diclometan-water (3.5:1:0.1, flow rate $2 \mathrm{ml} / \mathrm{min})$ to yield compound 9 (26 mg).

The fraction eluted by $50 \% \mathrm{MeOH}(18 \mathrm{~g})$ was separated over silica gel $(\Phi=2 \mathrm{~cm}$, height of silica gel $60 \mathrm{~cm}$ ) with $\mathrm{CH}_{2} \mathrm{Cl}_{2}-\mathrm{MeOH}$-water (4:1:0.1, flow rate $2 \mathrm{ml} / \mathrm{min}$ ) to obtain nine fractions (Fr.7A-7I). Fraction 7D $(2.6 \mathrm{~g})$ produced a precipitate of crude crystals, which was separated by filtering and washing with $\mathrm{MeOH}$ to yield compound 4 (200 mg). The purity of isolated compounds was more than $95 \%$ by HPLC analysis.

\section{Soulameanone}

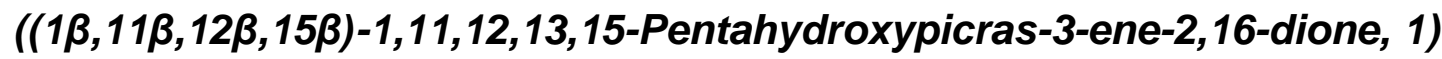

White powder of mp $263-265^{\circ} \mathrm{C}, \mathrm{C}_{20} \mathrm{H}_{28} \mathrm{O}_{8} .{ }^{1} \mathrm{H}-\mathrm{NMR}\left(500 \mathrm{MHz}\right.$, DMSO-d $\left.\mathrm{d}_{6}\right): \delta 6.29$ (bs, 15$\mathrm{OH}), 5.97$ (s, H-3), 5.69 (bs, 13-OH), 4.86 (bs, H-7), 4.78 (bs, 12-OH), 4.53 (bs, 1-OH), 4.27 (dd, $\mathrm{J}=6.5,2.0 \mathrm{~Hz}, \mathrm{H}-15), 4.13$ (s, H-1), 4.07 (bs, H-11), 4.07 (bs, 11-OH), 3.47 (dd, $\mathrm{J}=6.5,2.5 \mathrm{~Hz}, \mathrm{H}-12), 2.88(\mathrm{t}, \mathrm{J}=6.5 \mathrm{~Hz}, \mathrm{H}-5), 2.08(\mathrm{~m}, \mathrm{H}-6), 1.95$ (s, H-9), 1.95 (s, H-14), 1.93 (s, H-18), 1.36 (s, H-20), 1.05 (s, H-19), 0.92 (s, H-21). ${ }^{13} \mathrm{C}-N M R$ (DMSO-d, 125 $\mathrm{MHz}$ ): $\delta 198.2$ (s, C-2), 171.4 (s, C-16), 164.0 (s, C-4), 124.3 (d, C-3), 82.1 (d, C-1), 78.1 (d, C-7), 78.0 (d, C-12), 74.8 (d, C-11), 71.8 (s, C-13), 66.7 (d, C-15), 60.5 (d, C-14), 47.1 (s, C-10), 44.8 (d, C-9), 42.6 (d, C-5), 37.8 (s, C-8), 28.8 (q, C-20), 24.4 (t, C-6), 21.9 (q, C-187), 17.8 (q, C-21), 12.9 (q, C-19). HRESIMS: calcd for $\mathrm{C}_{20} \mathrm{H}_{29} \mathrm{O}_{8}$ : 397.4315. found: 397.1862. 


\section{Isobruceine $B$}

(Methyl (1 $\beta, 11 \beta, 12 \alpha, 15 \beta)-15-(a c e t y l o x y)-1,11,12-t r i h y d r o x y-2,16-d i o x o-$ 13,20-epoxypicras-3-en-21-oate, 2)

Yellow powder of mp 243-246 ${ }^{\circ} \mathrm{C}, \mathrm{C}_{23} \mathrm{H}_{28} \mathrm{O}_{11} \cdot{ }^{1} \mathrm{H}-\mathrm{NMR}\left(500 \mathrm{MHz}, \mathrm{CDCl}_{3}\right)$ : $\delta 6.34$ (bs, $\left.\mathrm{H}-15\right)$, 6.11 (s, H-3), 4.81 (d, J = 7.5 Hz, H-20ß), 4.75 (d, J = 3.0 Hz, H-11), 4.74 (d, J = 3.0 Hz, H-7), 4.28 (d, $\mathrm{J}=1.0 \mathrm{~Hz}, \mathrm{H}-12), 4.17$ (s, H-1), 2.92 (d, J = 12.5 Hz, H-5), 3.83 (s, H-1'), 3.75 (dd, J = 8.0, 1.5 Hz, H-

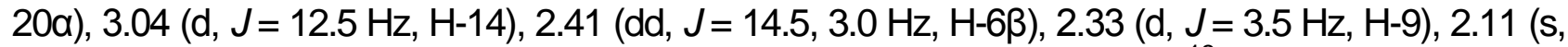
H-2"), 1.95 (s, H-18), 1.86 (ddd, J = 13.0, 2.5, $2.5 \mathrm{~Hz}, \mathrm{H}-6 \mathrm{\alpha}), 1.18$ (s, H-19). ${ }^{13} \mathrm{C}-\mathrm{NMR}\left(\mathrm{CDCl}_{3}, 125\right.$ MHz): $\delta 196.9$ (s, C-2), 172.6 (s, C-21), 169.0 (s, C-1"), 166.8 (s, C-16), 162.9 (s, C-4), 124.3 (d, C-3), 83.0 (d, C-7), 81.1 (d, C-1), 80.5 (s, C-13), 75.8 (d, C-12), 73.3 (t, C-20), 72.4 (d, C-11), 67.0 (d, C-15), 53.0 (q, C-1', OCH $\mathrm{OCH}_{3}$ ), 51.5 (d, C-14), 47.5 (s, C-10), 45.6 (s, C-8), 43.5 (d, C-5), 42.8 (d, C-9), 28.5 (t, C-6), 22.5 (q, C-18), 20.3 (q, C-2"), 11.5 (q, C-19). ESIMS (m/z, \%): 480.7 ([M+ H] $\left.]^{+}, 100\right)$.

\section{9-Methoxycanthin-6-one}

\section{(9-Methoxy-6H-indolo[3,2,1-de][1,5]naphthyridin-6-one, 3)}

Yellow powder of mp $178-180^{\circ} \mathrm{C}, \mathrm{C}_{15} \mathrm{H}_{10} \mathrm{~N}_{2} \mathrm{O}_{2} \cdot{ }^{1} \mathrm{H}-\mathrm{NMR}\left(500 \mathrm{MHz}, \mathrm{CDCl}_{3}\right): \delta 8.74(\mathrm{~d}, \mathrm{~J}=$ $5.0 \mathrm{~Hz}, \mathrm{H}-2), 8.16$ (d, J = 2.0 Hz, H-8), 7.98 (d, $\mathrm{J}=9.5 \mathrm{~Hz}, \mathrm{H}-4), 7.90$ (d, J = $8.5 \mathrm{~Hz}, \mathrm{H}-11$ ), $7.80(\mathrm{~d}, \mathrm{~J}=5.0 \mathrm{~Hz}, \mathrm{H}-1), 7.04$ (dd, J = 8.5, 2.0 Hz, H-10), 6.93 (d, J = 9.5 Hz, H-5), 3.97 (s, $\mathrm{H}-17) .{ }^{13} \mathrm{C}-N M R\left(125 \mathrm{MHz}, \mathrm{CDCl}_{3}\right.$ ): $\delta 162.5$ (s, C-9), 159.7 (s, C-6), 146.0 (d, C-2), 141.2 (s, C-13), 139.9 (d, C-4), 135.7 (s, C-16), 132.3 (s, C-15), 130.4 (s, C-14), 128.5 (d, C-5), 123.3 (d, C-11), 117.2 (s, C-12), 115.5 (d, C-1), 114.2 (d, C-10), 101.3 (d, C-8), 56.0 (q, C17). HRESIMS: calcd for $\mathrm{C}_{15} \mathrm{H}_{11} \mathrm{~N}_{2} \mathrm{O}_{2}$ : 251.0742. found: 251,0820 .

\section{Bruceolline $F$}

(1-(1-ß-D-glucopyranosyl-1H-indol-3-yl)-3-methylbutane-2,3-diol, 4)

Yellow powder of $\mathrm{mp} 209-211^{\circ} \mathrm{C}, \mathrm{C}_{19} \mathrm{H}_{27} \mathrm{NO}_{7} .{ }^{1} \mathrm{H}-\mathrm{NMR}(500 \mathrm{MHz}$, DMSO-d $)$ : $\delta 7.54(\mathrm{~d}, \mathrm{~J}=$ $7.5 \mathrm{~Hz}, \mathrm{H}-4), 7.50$ (d, J = 8,0 Hz, H-7), 7.28 (s, H-2), 7.12 (t, J =7.5 Hz, H-6), 7.03 (t, J = 7.5 $\mathrm{Hz}, \mathrm{H}-5), 5.37$ (d, J = 9.5 Hz, H-1"), 5.18 (d, J = 5.0 Hz, 3"-OH), 5.10 (d, J = $5.5 \mathrm{~Hz}, 2^{\prime \prime}-\mathrm{OH}$ ), $5.10\left(\mathrm{~d}, \mathrm{~J}=5.5 \mathrm{~Hz}, 4^{\prime \prime}-\mathrm{OH}\right), 4.56(\mathrm{t}, \mathrm{J}=5.5 \mathrm{~Hz}, 6 "-\mathrm{OH}), 4.34(\mathrm{~d}, \mathrm{~J}=5.5 \mathrm{~Hz}, 2 \mathrm{\prime}-\mathrm{OH}), 4.29(\mathrm{~s}$, 3'-OH), 3.73 (dt, J = 8.5, 5.5 Hz, H-2"), 3.70 (ddd, J = 13.5, 9,0, 3.5 Hz, H-6"a), 3.46 (m, H5"), 3.45 (m, H-6"b), 3.44 (d, J =10.5 Hz, H-2'), 3.42 (dt, J = 9.0, 5.0 Hz, H-3"), 3.26 (dt, J = 9.0, 5.5Hz, H-4"), 3.05 (d, J =15.0 Hz, H-1'a), 2.46 (dd, J = 14.5, 10.5 Hz, H-1'b), 1.17 (s, H5'), $1.14\left(\mathrm{~s}, \mathrm{H}-4^{\prime}\right) .{ }^{13} \mathrm{C}-\mathrm{NMR}\left(125 \mathrm{MHz}, \mathrm{DMSO}-\mathrm{d}_{6}\right): \delta 136.5$ (s, C-8), 128.6 (s, C-9), 123.7 (d, C-2), 121.0 (d, C-6), 118.8 (d, C-5), 118.8 (d, C-4), 113.8 (s, C-3), 110.5 (d, C-7), 84.5 (d, C-1"), 79.3 (d, C-5"), 77.8 (d, C-2'), 77.5 (d, C-3"), 71.9 (d, C-2"), 71.8 (s, C-3'), 70.0 (d, C-4"), 61.0 (t, C-6"), 27.0 (t, C-1'), 26.9 (q, C-5'), 24.2 (q, C-4'). ESIMS (m/z, \%): 418.0 $\left(\left[\mathrm{M}+2 \mathrm{H}_{2} \mathrm{O}+\mathrm{H}\right]^{+}, 100\right)$.

\section{Niloticin}

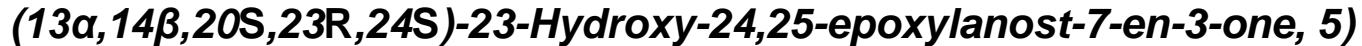

Yellow powder of mp $147-149^{\circ} \mathrm{C}, \mathrm{C}_{30} \mathrm{H}_{48} \mathrm{O}_{3} .{ }^{1} \mathrm{H}-\mathrm{NMR}\left(500 \mathrm{MHz}, \mathrm{CDCl}_{3}\right) \delta 5.32(\mathrm{~m}, \mathrm{H}-7)$, 3.57 (m, H-23), 2.76 (dt, J = 14.5, $5.5 \mathrm{~Hz}, \mathrm{H}-1 \mathrm{a}), 2.66$ (d, J = 8.5 Hz, H-24), 2.23 (t, J = 3.5 $\mathrm{Hz}, \mathrm{H}-1 \mathrm{~b}), 2.27$ (t, J = 3.5 Hz, H-9), 2.10 (t, J = 3.5 Hz, H-6), 2.05 (m, H-16a), 2.02 (m, H2a), $1.82(\mathrm{~m}, \mathrm{H}-12 \mathrm{a}), 1.72(\mathrm{~d}, \mathrm{~J}=8.5 \mathrm{~Hz}, \mathrm{H}-5), 1.66(\mathrm{~m}, \mathrm{H}-22 \mathrm{a}), 1.65(\mathrm{~m}, \mathrm{H}-20), 1.64(\mathrm{~m}$, $\mathrm{H}-11), 1.58$ (m, H-17), 1.50 (m, H-15), 1.49 (m, H-2b), 1.44 (m, H-22b), 1.42 (m, H-12b), 1.33 (s, H-26), 1.32 (s, H-27), 1.23 (m, H-16b), 1.12 (s, H-29), 1.05 (s, H-28), 1.03 (s, H- 
30), 1.01 (s, H-19), 0.96 (d, J = $6.0 \mathrm{~Hz}, \mathrm{H}-21), 0.82$ (s, H-18). ${ }^{13} \mathrm{C}-\mathrm{NMR}\left(125 \mathrm{MHz}, \mathrm{CDCl}_{3}\right)$ : ठ 216.9 (s, C-3), 145.7 (s, C-8), 118.0 (d, C-7), 69.3 (t, C-23), 68.5 (d, C-24), 60.3 (s, C-25), 53.3 (d, C-17), 52.4 (d, C-5), 51.2 (s, C-14), 48.5 (d, C-9), 47.9 (s, C-4), 43.6 (s, C-13), 40.7 (t, C-22), 38.6 (t, C-2), 35.0 (s, C-10), 34.9 (t, C-1), 34.0 (t, C-15), 33.6 (t, C-12), 33.6 (d, C20), 28.8 (t, C-16), 27.4 (q, C-30), 24.9 (q, C-27), 24.6 (q, C-28), 24.4 (t, C-6), 21.8 (q, C-18), 21.6 (q, C-29), 19.9 (q, C-2), 19.8 (q, C-26), 18.3 (t, C-11), 12.8 (q, C-19). HRESIMS: calcd for $\mathrm{C}_{30} \mathrm{H}_{49} \mathrm{O}_{3}: 457.3603$. found: 457.3682 .

\section{Octatriacontan-1-ol (6)}

White powder, $\mathrm{C}_{38} \mathrm{H}_{78} \mathrm{O} .{ }^{1} \mathrm{H}-\mathrm{NMR}\left(400 \mathrm{MHz}, \mathrm{CDCl}_{3}\right)$ : $\delta 3.49\left(2 \mathrm{H},-\mathrm{CH}_{2}-\mathrm{O}\right), 1.45\left(2 \mathrm{H}, \mathrm{m}, \mathrm{CH}_{2}\right)$, $1.16\left(70 \mathrm{H}, 35 \mathrm{CH}_{2}\right), 0.78\left(3 \mathrm{H}, \mathrm{m}, \mathrm{CH}_{3}\right) .{ }^{13} \mathrm{C}-\mathrm{NMR}\left(100 \mathrm{MHz}, \mathrm{CDCl}_{3}\right): \delta 62.3\left(\mathrm{t},-\mathrm{CH}_{2}-\mathrm{O}-\right), 22.4-$ $32.3\left(\mathrm{t}, 36 \mathrm{CH}_{2}\right), 13.7\left(\mathrm{q}, \mathrm{CH}_{3}\right)$. ESIMS (m/z, \%): $550.6\left([\mathrm{M}+\mathrm{H}]^{+}, 100\right)$

\section{Bombiprenone}

(5E,9E,13E,17E,21E,25E,29E)-6,10,14,18,22,26,30,34-Octamethylpentatriaconta$5,9,13,17,21,25,29,33-o c t a e n-2-o n e, 7)$

Yellow powder, $\mathrm{C}_{43} \mathrm{H}_{70} \mathrm{O} .{ }^{1} \mathrm{H}-\mathrm{NMR}\left(500 \mathrm{MHz}, \mathrm{CDCl}_{3}\right)$ : $\delta$ 5.10-5.13 $(7 \mathrm{H}, \mathrm{H}-9, \mathrm{H}-13, \mathrm{H}-17, \mathrm{H}-$ 21, H-25, H-29, H-33), $5.08(1 \mathrm{H}, \mathrm{H}-5), 2.45(2 \mathrm{H}, \mathrm{t}, \mathrm{J}=7.5 \mathrm{~Hz}, \mathrm{H}-3), 2.27(2 \mathrm{H}, \mathrm{t}, \mathrm{J}=7.5 \mathrm{~Hz}$, $\mathrm{H}-4), 2.13(3 \mathrm{H}, \mathrm{s}, \mathrm{H}-1), 2.05-2.09(14 \mathrm{H}, \mathrm{t}, \mathrm{J}=7.5 \mathrm{~Hz}, \mathrm{H}-8, \mathrm{H}-12, \mathrm{H}-16, \mathrm{H}-20, \mathrm{H}-24, \mathrm{H}-28$, $\mathrm{H}-32), 1.97-2.00(14 \mathrm{H}, \mathrm{t}, \mathrm{J}=7.5 \mathrm{~Hz}, \mathrm{H}-7, \mathrm{H}-11, \mathrm{H}-15, \mathrm{H}-19, \mathrm{H}-23, \mathrm{H}-27, \mathrm{H}-31), 1.57-$ $1.60(21 \mathrm{H}, \mathrm{s}, \mathrm{H}-34 \div 40), 1,68(3 \mathrm{H}, \mathrm{s}, \mathrm{H}-42), 1,62(3 \mathrm{H}, \mathrm{s}, \mathrm{H}-43) .{ }^{13} \mathrm{C}-\mathrm{NMR}(125 \mathrm{MHz}$, $\mathrm{CDCl}_{3}$ ): $\delta 208.8$ (s, C-2), 134.9-136.5 (s, C-6, C-10, C-14, C-18, C-22, C-26, C-30), 131.2 (s, C-41), 124.1-124.4 (d, C-9, C-13, C-17, C-21, C-25, C-29, C-33), 122.5 (d, C-5), 43.8 (t, C-3), 39.7 (t, C-7, C-11, C-15, C-19, C-23, C-27, C-31), 29.9 (q, C-1), 26.6-26.8 (t, C-8, C-12, C-16, C-20, C-24, C-28, C-32), 25.7 (q, C-42), 22.5 (t, C-4), 17.7 (q, C-43), 16.0 (q,

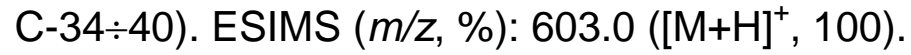

\section{a-Tocopherol}

(2,5,7,8-tetramethyl-2-[(4R,8R)-4,8,12-trimethyltridecyl]-3,4-dihydro-2H-chromen-6-ol, 8)

Red powder, $\mathrm{C}_{29} \mathrm{H}_{50} \mathrm{O}_{2} .{ }^{1} \mathrm{H}-\mathrm{NMR}\left(500 \mathrm{MHz}, \mathrm{CDCl}_{3}\right): \delta 2.60$ (t), $2.16(\mathrm{~s}), 2.11$ (s), 1.72-1.84 (m), 1.47-1.57 (m), 1.21-1.39 (m), $1.22(3 \mathrm{H}, \mathrm{s}), 1.05-1.16(\mathrm{~m}), 0.84(\mathrm{~d}, \mathrm{~J}=4.5 \mathrm{~Hz}), 0.86$

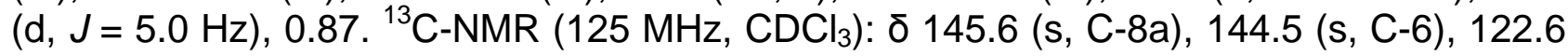
(s, C-8), 121.0 (s, C-7), 118.5 (s, C-5), 117.4 (s, C-4a), 74.5 (s, C-2), 39.8 (t, C-1'), 39.4 (t, C-11'), 37.3-37.5 (t, C-3', C-5', C-7', C-9'), 32.8 (d, C-4', C-8'), 31.6 (t, C-3), 28.0 (d, C-12'), 24.8 (t, C-10'), 24.5 (t, C-6'), 23.8 (q, C-2a), 22.6 (q, C-12'a), 22.7 (q, C-13'), 21.1 (t, C-2'), 20.8 (t, C-4), 19.8 (q, C-4'a, C-8'a), 12.2 (q, C-7a), 11.8 (q, C-8b), 11.3 (q, C-5a). ESIMS $(\mathrm{m} / \mathrm{z}, \%): 431.6\left([\mathrm{M}+\mathrm{H}]^{+}, 100\right)$.

\section{Inosine}

\section{(9-ß-D-Ribofuranosyl-9H-purin-6-ol, 9)}

White powder, mp. $215^{\circ} \mathrm{C}, \mathrm{C}_{10} \mathrm{H}_{12} \mathrm{~N}_{4} \mathrm{O}_{5} \cdot{ }^{1} \mathrm{H}-\mathrm{NMR}\left(500 \mathrm{MHz}, \mathrm{CD}_{3} \mathrm{OD}\right): \delta 8.33$ (s, H-8), 8.21 (s, H-2), 6.00 (d, J = 6.5 Hz, H-1'), 4.76 (t, J = 5.8 Hz, H-2'), 4.36 (dd, J = 5.0, $2.5 \mathrm{~Hz}, \mathrm{H}-$ 3'), 4.22 (q, J = 2.5 Hz, H-4'), 3.91 (dd, $J=13.0,2.5 \mathrm{~Hz}, \mathrm{H}-5$ 'a), 3.79 (dd, $J=12.5,2.5 \mathrm{~Hz}$, $\mathrm{H}-5$ 'b). ${ }^{13} \mathrm{C}-\mathrm{NMR}\left(125 \mathrm{MHz}, \mathrm{CD}_{3} \mathrm{OD}\right.$ ): $\delta 157.4$ (s, C-6), 153.5 (d, C-2), 149.9 (s, C-4), 142.0 (d, C-8), 120.9 (s, C-5), 91.0 (d, C-1'), 88.0 (d, C-4'), 75.4 (d, C-2'), 72.5 (d, C-3'), 63.3 (t, C-5'). ESIMS (m/z, \%): $269.5\left([\mathrm{M}+\mathrm{H}]^{+}, 100\right)$ 


\section{Apigenin 7-0- $\beta$-D-glucopyranoside}

\section{(5-Hydroxy-2-(4-hydroxyphenyl)-4-oxo-4H-chromen-7-yl $\beta$-D-glucopyranoside, 10)}

Yellow powder, mp. $238-239^{\circ} \mathrm{C}, \mathrm{C}_{21} \mathrm{H}_{20} \mathrm{O}_{10} \cdot{ }^{1} \mathrm{H}-\mathrm{NMR}\left(500 \mathrm{MHz}, \mathrm{DMSO}-d_{6}\right): \delta 12.97$ (s, 5$\mathrm{OH}$ ), 10.37 (s, 4'-OH), 7.95 (d, J = 9.0 Hz, H-5'), 6.93 (d, J = 8.5 Hz, H-6'), 6.87 (s, H-3), $6.83(\mathrm{~d}, \mathrm{~J}=2.0 \mathrm{~Hz}, \mathrm{H}-6), 6.44(\mathrm{~d}, \mathrm{~J}=2.0 \mathrm{~Hz}, \mathrm{H}-8), 5.06(\mathrm{~d}, \mathrm{~J}=7.5 \mathrm{~Hz}, \mathrm{H}-1 ")$. ${ }^{13} \mathrm{C}-\mathrm{NMR}$ (125 MHz, DMSO-d ): $\delta 182.0$ (s, C-4), 164.3 (s, C-7), 163.0 (s, C-5), 161.1 (s, C-2, C-9), 156.9 (s, C-4'), 128.6 (d, C-2', C-5'), 121.0 (s, C-1'), 116.0 (d, C-3', C-6'), 105.3 (s, C-10), 103.1 (d, C-3), 99.9 (d, C-1"), 99.5 (d, C-6), 94.8 (d, C-8), 77.2 (d, C-5"), 76.4 (d, C-3"), 73.1 (d, C-2"), 69.5 (d, C-4"), 60.6 (t, C-6").

\section{Cytotoxicity assay}

KB (human carcinoma of the mouth), LU-1 (human lung adenocarcinoma), and LNCaP (human prostate adenocarcinoma) cell lines, obtained from ATCC (American Type Culture Collection, Manassas, VA), were maintained as monolayers in DMEM supplemented with $10 \%$ fetal bovine serum (FBS; GIBCO, Grant Island, NY), sodium bicarbonate, penicillin G, and streptomycin at $37^{\circ} \mathrm{C}$ under a humidified atmosphere of $5 \% \mathrm{CO}_{2}$. HL-60 (human promyelocytic leukemia) cells were grown suspensively in RPMI-1640 medium under the same conditions as the other cell lines. The cytotoxic activity of the tested compounds was measured using the sulforhodamine B (SRB) method [21]. Viable cells were seeded $(180 \mu \mathrm{L})$ in 96 -well microtiter plates at a concentration of $3 \times 10^{4}$ cells $/ \mathrm{mL}$ and allowed to attach overnight. The test samples were dissolved in 10\% DMSO and adjusted to a final working concentration of $100 \mu \mathrm{g} / \mathrm{mL}$ by diluting with the growth medium. Samples were prepared in triplicate. The final DMSO concentration was adjusted to less than $0.1 \%$. The assay duration was three days. One plate without samples served as a 0-day control. Test plates were incubated in a humidified atmosphere of $5 \% \mathrm{CO}_{2}$ at $37^{\circ} \mathrm{C}$ for another $72 \mathrm{~h}$, while the 0-day control was incubated for $1 \mathrm{~h}$. After incubation, the medium was removed, except for the HL-60 cell experiments. The remaining cells were fixed using $10 \%$ trichloroacetic acid (TCA) for $1 \mathrm{~h}$ at $4^{\circ} \mathrm{C}$. Plates containing HL-60 cells were fixed using $70 \%$ TCA for $2 \mathrm{~h}$ at $4^{\circ} \mathrm{C}$. The TCA-treated cells were then washed extensively with water and dried in air. Once fixed cell plates dried completely, $50 \mu \mathrm{L}$ of SRB solution $(0.4 \%$ in acetic acid) was added to each well at room temperature. After standing for $1 \mathrm{~h}$, the wells were washed 3-4 times with 1\% acetic acid and dried in air. Subsequently, the bound dye was solubilized by the addition of $10 \mathrm{mmol}$ of unbuffered Tris base (Sigma, Louis, MO). The absorption was measured at $515 \mathrm{~nm}$ with a microplate reader (BioRad, Hercules, CA). Growth, expressed as a percentage of the negative control, was calculated as follows: $\%$ growth $=$ [absorbance (test substance) - absorbance (0-day control) $]$ * 100 I [absorbance (negative control) - absorbance (0-day control)].

The $I C_{50}$ values (inhibitory concentration at 50\%) were determined by plotting concentrations against \% growth using nonlinear regression analysis (TableCurve software, San Jose, CA).

\section{Acknowledgement}

We thank the Ministry of Science and Technology, Vietnam, for financial support in a form of the Vietnam - Korea International Collaboration Project (52/2011/HD-NDT). This work was partly supported by the Vietnam Academy of Science and Technology. 


\section{Authors' Statement}

\section{Competing Interests}

The authors declare no conflict of interest.

\section{References}

[1] Kitagawa I, Mahmud T, Simanjuntak P, Hori K, Uji T, Shibuya $\mathrm{H}$.

Indonesian medicinal plants. VIII. Chemical structures of three new triterpenoids, bruceajavanin $A$, dihydrobruceajavanin A, and bruceajavanin B, and a new alkaloidal glycoside, bruceacanthinoside, from the stems of Brucea javanica (Simaroubaceae).

Chem Pharm Bull. 1994; 42: 1416-1421.

http://dx.doi.org/10.1248/cpb.42.1416

[2] Jian-Hua L, Hui-Zi J, Wei-Dong Z, Shi-Kai Y, and Yun-Heng S.

Chemical constituents of plants from the genus Brucea.

Chem Biodivers. 2009; 6: 57-70.

http://dx.doi.org/10.1002/cbdv.200700409

[3] Pham Hoang Ho.

An illustrated flora of Vietnam.

Hanoi: Young Publishing House; 2000; 2: 383-386.

[4] Koichi T, Hideyuki K, Hiroshi M, Xu-Rong Q and Hideji I.

Quassinoids from Brucea mollis Wall.

Nat Med. 1996; 50: 368-368.

[5] Hui C, Jian B, Zhen-Feng F, Shi-Shan Y, Shuang-Gang M, Song X, Yong L, Jing Q, Jin-Hong R, Li L. Indole alkaloids and quassinoids from the stems of Brucea mollis.

J Nat Prod. 2011; 74: 2438-2445.

http://dx.doi.org/10.1021/np200712y.

[6] Tung MHT, Đuc HV, Huong TT, Cuong NM.

Cytotoxic properties of Brucea mollis leaves.

Vietnam J Med Mater. 2011; 16: 356-360.

[7] Judith P, Tri MV, Zoia V, Thierry P, Claudine P, Thierry S, Jacques S.

Quassinoids. Isolation from Soulamea muelleri and structures of 1,12-di-O-acetylsoulameanone and $\Delta^{2}$-picrasin B. X-ray analysis of soulameanone.

Tetrahedron. 1980; 36: 2983-2988.

http://dx.doi.org/10.1016/0040-4020(80)88023-9

[8] Narihiko F, Masayoshi O.

Antitumor agents, 93. Bruceanol C, a new cytotoxic quassinoid from Brucea antidysenterica.

J Nat Prod. 1988; 51: 349-352.

http://dx.doi.org/10.1021/np50056a031

[9] Kardono LBS, Angerhofer CK, Tsauri S, Padmawinata K, Pezzuto JM, Kinghorn AD.

Cytotoxic and antimalarial constituents of the roots of Eurycoma longifolia.

J Nat Prod. 1991; 54: 1360-1367.

http://dx.doi.org/10.1021/np50077a020

[10] Ouyang Y, Koike K, Ohmoto T.

Indole alkaloids from Brucea mollis var. tonkinensis.

Phytochemistry. 1994; 37: 575-578.

http://dx.doi.org/10.1016/0031-9422(94)85103-4

[11] Yan C, Wang Y, Hao XJ.

Triterpenes from the fruits of Phellodendron chinense Schneid var. glabriusculum Schneid.

Chin J Nat Med. 2009; 7: 31-33.

http://dx.doi.org/10.3724/SP.J.1009.2009.00031 
[12] Matsuo M, Urano S.

13C NMR spectra of tocopherols and 2,2-dimethylchromanols.

Tetrahedron. 1976; 32: 229-231.

http://dx.doi.org/10.1016/0040-4020(76)87006-8

[13] Kin-ichi O, Tadao K.

Total synthesis of apigenin 7,4'-di-O- $\beta$-glucopyranoside, a component of blue flower pigment of Salvia patens, and seven chiral analogues.

Tetrahedron. 2004; 60: 2025-2034.

http://dx.doi.org/10.1016/j.tet.2004.01.001

[14] Ukai K, Kirihara S, Fujikawa Y, Notoya M, Namikoshi M.

Identification of two nucleosides, inosine and guanosine, in the bioactive fraction from Solaster dawsoni, which induced escape response in Asterina pectinifera.

Journal of Tokyo University of Fisheries. 2002; 88: 7-13.

[15] Imamura K, Fukamiya N, Okano M.

Bruceanols D, E and F. Three new cytotoxic quassinoids from Brucea antidysenterica.

J Nat Prod. 1993; 56: 2091-2097.

http://dx.doi.org/10.1021/np50102a010

[16] Pohlit AM, Jabor VAP, Amorim RCN, Silva ECC, Lopes NP.

LC-ESI-MS determination of quassinoids isobrucein B and neosergeolide in Picrolemma sprucei stem infusions.

J Braz Chem Soc. 2009; 20: 1065-1070.

http://dx.doi.org/10.1590/S0103-50532009000600010

[17] Silva ECC, Cavalcanti BC, Amorim RCN, Lucena JF, Quadros DS, Tadei WP, Montenegro RC, CostaLotufo LV, Pessoa C, Moraes MO, Nunomura RCS, Nunomura SM, Melo MRS,

Andrade-Neto VF, Silva LFR, Vieira PPR, Pohlit AM.

Biological activity of neosergeolide and isobrucein B (and two semi-synthetic derivatives) isolated from the Amazonian medicinal plant Picrolemma sprucei (Simaroubaceae).

Memorias do Instituto Oswaldo Cruz. 2009; 104: 48-55.

http://dx.doi.org/10.1590/S0074-02762009000100008

[18] Guo Z, Vangapandu S, Sindelar RW, Walker LA, Sindelar RD.

Biologically active quassinoids and their chemistry: potential leads for drug design.

Curr Med Chem. 2005; 12: 173-190.

http://dx.doi.org/10.2174/0929867053363351

[19] Mitsunaga K, Koike K, Tanaka T, Ohkawa Y, Kobayashi Y, Sawaguchi T, Ohmoto T.

Canthin-6-one alkaloids from Eurycoma longifolia.

Phytochemistry. 1994; 35: 799-802.

http://dx.doi.org/10.1016/S0031-9422(00)90609-5

[20] Mei-Xiang, Ying-Jun Zhou.

Canthin-6-one alkaloids from Picrasma quassioides and their cytotoxic activity.

J Asian Nat Prod Res. 2008; 10: 1009-1012.

http://dx.doi.org/10.1080/10286020802277956

[21] Skehan P, Storeng R, Scudiero D, Monks A, McMahon J, Vistica D, Warren JT, Bokesch H, Kenney S, Boyd MR.

New Colorimetric Cytotoxicity Assay for Anticancer-Drug Screening.

J Natl Cancer Inst. 1990; 82: 1107-1112.

http://www.ncbi.nlm.nih.gov/pubmed/2359136 